\title{
Bactericidal effect of selected spices, medicinal plants and tea on Helicobacter pylori strains from Sri Lanka
}

\author{
Deepaka Weerasekera ${ }^{1}$, Neluka Fernando ${ }^{2 *}$, L.B.A.E. Bogahawatta ${ }^{2}$, R. Rajapakse-Mallikahewa ${ }^{2}$ and \\ D.J. Naulla ${ }^{2}$ \\ 1 Department of Surgery, Faculty of Medical Science, University of Sri Jayewardenepura, Gangodawila, Nugegoda. \\ 2 Department of Microbiology, Faculty of Medical Science, University of Sri Jayewardenepura, Gangodawila, Nugegoda.
}

\begin{abstract}
The bactericidal activity of 21 plant extracts on Helicobacter pylori was investigated. Plants were boiled in water to produce aqueous extracts. Bactericidal activity of the extracts was assessed by a standard kill-curve using five strains of H. pylori isolated from Sri Lanka and the NCTC 11637 strain. Among the plants that showed bactericidal activity for H.pylori, turmeric and ginger were the most efficient followed by chilli and black tea. Nutmeg, liquorice, cinnamon, colombo weed, yellow-berried nightshade, threadstem carpetweed, sage, parsley, long pepper, and cumin also showed bactericidal activity against $H$. pylori. These could serve as potent alternative therapies for H. pylori infection, avoiding the problem of resistance associated with current antibiotic treatment.
\end{abstract}

Keywords: Bactericidal effect, ginger, Helicobacter pylori, inhibition, medicinal, plants, Sri Lanka, turmeric

\section{INTRODUCTION}

Helicobacter pylori is a strict human pathogen which has colonized half the world population ${ }^{1}$. If untreated it can lead to chronic active disease and gastric malignancy. According to current recommendations, treatment of infection by $H$. pylori includes triple therapy inclusive of a proton pump inhibitor.

Although antibiotic resistance of $H$. pylori is not known in Sri Lanka, it is reported to be increasing world over. The need therefore arises to find an alternative with anti microbial properties. Studies conducted mainly in the developed countries have demonstrated inhibition of $H$. pylori by extracts of ginger, black tea, garlic, thyme, and $\operatorname{mint}^{2-6}$. The overall data for the prevalence of $H$. pylori in Sri Lanka differ from 3-70 \% and seems to correspond more to that of an industrialized country ${ }^{7,8}$.
The reason for the low prevalence of $H$. pylori in Sri Lanka is an enigma. One of the reasons for the low prevalence may be the Sri Lankan diet. Rice is the staple food in a Sri Lankan traditional diet with a significant contribution from bread, pulses and vegetables. Spices and chilli are essential and popular additives to food. Tea is consumed in plenty.

A study in the UK used Italian strains of $H$. pylori to test the bactericidal activity of spices, tea and medicinal plants. The results of the study demonstrated inhibitory action in some of the tested plants extracts ${ }^{6}$.

The genetic composition of $H$. pylori strains differ in various geographic regions of the world ${ }^{6}$ and this study was designed to determine the inhibitory effects of certain spices, medicinal plants and tea against $H$. pylori strains isolated from Sri Lanka.

\section{METHODS AND MATERIALS}

Isolation of H. pylori: H. pylori NCTC 11637 and five strains of $H$. pylori isolated from patients presenting with peptic ulcer disease were included in the study. All strains were stored on beads at $-80^{\circ} \mathrm{C}$ until tests were performed. Bacteria were grown on Colombia blood agar (oxoid) plates supplemented with 5\% sheep blood at $37^{\circ} \mathrm{C}$ under micro aerophilic conditions.

Preparation of extracts: $10 \mathrm{~g}$ of each powdered substance (refer to Table 1) was dissolved in $100 \mathrm{~mL}$ of distilled water $(100 \mathrm{mg} / \mathrm{mL}$ ) and was boiled for $20 \mathrm{~min}$. The extracts were filtered through sterile gauze and $\mathrm{pH}$ neutralized. Finally the extracts were sterilized by autoclaving. All extracts were stored in the dark at $-20{ }^{\circ} \mathrm{C}$ until use. 
Viable colony count: Bactericidal activities of the extracts were determined by viable colony counts. One hundred micro liters $(\mu \mathrm{L})$ of bacterial suspension $\left(5 \times 10^{8}\right)$ from the NCTC strain and the five isolates were added to $900 \mu \mathrm{L}$ of each of the test extracts and incubated for $60 \mathrm{~min}$ in gas jars under microaerophilic conditions. The control consisted of $H$. pylori incubated with sterile normal saline. At the end of $60 \mathrm{~min}, 100 \mu \mathrm{L}$ of this $1 / 10$ dilution was inoculated on to Colombia agar plates and incubated for $3 \mathrm{~d}$ under microaerophilic conditions. The colony count was determined for each of the extracts (colony forming units per milliliter, $\mathrm{cfu} / \mathrm{mL}$ ). Plant extracts that inhibited growth of $H$. pylori (i.e. no colonies grew) were further tested. As described above, 1 in 10 dilutions were prepared for all plant extracts and incubated for varying time intervals e.g. $0,15,30$, and $60 \mathrm{~min}$. $100 \mu \mathrm{L}$ of this $1 / 10$ dilution was then inoculated on to Colombia blood agar (oxoid) plates and incubated for $3 \mathrm{~d}$ under microaerophilic conditions. All experiments were performed three times. The effectiveness of the extracts in killing $H$. pylori was expressed as inhibition of colony growth.

\section{RESULTS}

Of the 21 plant extracts tested for bactericidal activity against $H$. pylori, 7 (fenugreek, coriander, bengal quince, nightshade, garlic, black pepper, fennel) did not show inhibition after 60 minutes of incubation under microaerophilic condition (Table 1).

Turmeric and ginger were the most efficient, with an ability to kill all 6 strains within 15 minutes. Chilli \& black tea were able to kill all 6 strains within 60 minutes. Incomplete bactericidal activity were observed for 10 extracts (Table 2)

\section{DISCUSSION}

In this study we have demonstrated the bactericidal properties of 21 plant extracts against $H$. pylori. The extracts were obtained simply by boiling selected parts of plants in water. The current treatment for $H$. pylori infection with combination of antibiotics, is expensive and associated with adverse side effects. Further, the development of resistance in $H$. pylori to antibiotics is also a problem.

Table 1: Plants used in the study

\begin{tabular}{|c|c|c|c|c|c|}
\hline $\begin{array}{l}\text { Common } \\
\text { English name }\end{array}$ & $\begin{array}{l}\text { Common } \\
\text { Sinhala name }\end{array}$ & Scientific name & Part of plant used & source & $\begin{array}{l}\text { Used (in food/ beverage/ } \\
\text { medicine }\end{array}$ \\
\hline Bengal quince & Belli & Aegle marmelos & Fruit & SL & in food and medicine \\
\hline Black pepper & Gammiris & Piper nigrum & Seed & SL & in food and medicine \\
\hline Black tea & Thē & Camellia sinensis & Leaves \& shoot & SL & in beverage \\
\hline Chilli & Miris & Capsicum anunum & Fruit & SL & in food and medicine \\
\hline Cinnamon & Curundu & Cinnamomum verum & Bark & SL & in food and medicine \\
\hline Calumba root & Veni'val & Coscinium fenestratum & Climbing stem & SL & in medicine \\
\hline Coriander & Kotta'malli & Coriandrum sativum & Fruit & SL & in food and medicine \\
\hline Cumin & Suduru & Cuminum cyminum & Seed & SL & in food and medicine \\
\hline Fennel & Ma'duru & Foeniculum officinalis & seed & SL & in food and medicine \\
\hline Fenugreek & Ulu' hal & Trigonella foenum-graecum & Seed & SL & in food and medicine \\
\hline Garlic & Sudu'lunu & Allium sativum & Bulb & SL & in food and medicine \\
\hline Ginger & E'guru & Zingiber officinale & Rhizome & SL & in food and medicine \\
\hline Liquorice & Val'mee & Glycyrrhiza glabra & Stem & SL & in medicine \\
\hline Long pepper & Thipili & Piper Longum & Seed & SL & in medicine \\
\hline Nightshade & Ela'battu & Solanum surattense & Fruit \& root & SL & in medicine \\
\hline Nutmeg & Sadikka & Myristica fragans & Kernel & SL & in food and medicine \\
\hline Parsley & Parsley & Petroselinum crispum & Leaves & SL & in food and medicine \\
\hline Sage & Minchi & Salvia officinalis & Leaves & SL & in food and medicine \\
\hline $\begin{array}{l}\text { Threadstem } \\
\text { carpetweed }\end{array}$ & Pathpardagam & Mollugo cerviana & Seed & SL & in medicine \\
\hline Turmeric & Kaha & Curcuma longa & Rhizome & SL & in food and medicine \\
\hline $\begin{array}{l}\text { Yellow-berried } \\
\text { nightshade }\end{array}$ & Katu'val'batu & Solanum xanthocarpum & Whole Plant & SL & in medicine \\
\hline
\end{tabular}


Table 2: The bactericidal activity of 21 extracts to $H$. pylori

\begin{tabular}{|c|c|c|c|c|c|c|}
\hline \multirow{3}{*}{$\begin{array}{l}\text { Common } \\
\text { English name }\end{array}$} & \multirow{3}{*}{$\begin{array}{l}\text { Common } \\
\text { Sinhala name }\end{array}$} & \multirow{2}{*}{\multicolumn{3}{|c|}{$\begin{array}{l}100 \% \text { inhibition } \\
\text { Time duration }\end{array}$}} & \multirow{3}{*}{$\begin{array}{l}\text { Incomplete inhibition } \\
\text { (Small colonies or } \\
\text { some growth) }\end{array}$} & \multirow[t]{3}{*}{ No activity } \\
\hline & & & & & & \\
\hline & & 15 & 30 & 60 & & \\
\hline Bengal quince & Belli & & & & & $\sqrt{ }$ \\
\hline Black pepper & Gammiris & & & & & $\sqrt{ }$ \\
\hline Black tea & Thē & & & $\sqrt{ }$ & & \\
\hline Chili & Miris & & & $\sqrt{ }$ & & \\
\hline Cinnamon & Curundu & & & & $\sqrt{ }$ & \\
\hline Columba root & Veni’val & & & & $\sqrt{ }$ & \\
\hline Coriander & Kotta'malli & & & & & $\sqrt{ }$ \\
\hline Cumin & Suduru & & & & $\sqrt{ }$ & \\
\hline Fennel & Ma'duru & & & & & $\sqrt{ }$ \\
\hline Fenugreek & Ulu’ hal & & & & & $\sqrt{ }$ \\
\hline Garlic & Sudu'lunu & & & & & $\sqrt{ }$ \\
\hline Ginger & E'guru & $\sqrt{ }$ & & & & \\
\hline Liquorice & Val'mee & & & & $\sqrt{ }$ & \\
\hline Long pepper & Thipili & & & & $\sqrt{ }$ & \\
\hline Nightshade & Ela'battu & & & & & $\sqrt{ }$ \\
\hline Nutmeg & Sadikka & & & & $\sqrt{ }$ & \\
\hline Parsley & Parsley & & & & $\sqrt{ }$ & \\
\hline Sage & Minchi & & & & $\sqrt{ }$ & \\
\hline Threadstem carpetweed & Pathpardagam & & & & $\sqrt{ }$ & \\
\hline Turmeric & Kaha & $\sqrt{ }$ & & & & \\
\hline Yellow-berried nightshade & Katu'val'batu & & & & $\sqrt{ }$ & \\
\hline
\end{tabular}

Seven plant extracts did not kill $H$. pylori after 60 minutes of incubation (black pepper, garlic, bengal quince, night shade, coriander, fenugreek and fennel) Several studies have shown that garlic does kill $H$. pylori in vitro and in vivo ${ }^{9,10}$. The observation in the current study may be due to the method of extraction. Boiling has been shown to reduce the inhibitory activity against $H$. pylori ${ }^{4,6,12}$. Fenugreek sprouts have been shown to have high antimicrobial activity against $H$. pylori ${ }^{11}$. In this study, fenugreek appeared inactive where the seeds were tested rather than sprouts, which may account for the difference in results, as compared to the European study ${ }^{6}$. In this study, only one Sri Lankan strain showed complete inhibition with cumin extract within one hour. However, in a study done in U.K., cumin extract was able to kill all strains within 30 minutes $^{6}$. This difference is interesting and should be studied further.

In this study, black tea and chilli extracts killed all the strains within one hour, but in the U.K. study ${ }^{6}$ no bactericidal activity against $H$. pylori was seen with black tea. The difference in these results may be due to different genotypes available in different geographic regions of the world. Green tea catechins have previously been reported to have antibacterial effect against $H$. pylori which was confirmed in Mongolian gerbils ${ }^{3}$.

The plant extracts of nutmeg, cinnamon, columbo weed, yellow-berried nightshade, liquorice, long pepper, threadstem carpetweed, sage, parsley \& cumin showed bactericidal activity against $H$. pylori but did not achieve complete inhibition within 60 minute.

As in the U.K. study ${ }^{6}$ we observed a reduced colony size with some spices such as sage, cinnamon, nutmeg, yellow-berried nightshade and threadstem carpetweed.

Extracts of turmeric and ginger were the most efficient and killed H. pylori. These results have been also shown by a previous study done in the $\mathrm{UK}^{6}$. However, it is the first time that anti $H$. pylori properties of spices have been demonstrated against strains isolated from Sri Lanka. These plant extracts can be used in combination with antibiotics, possibly increasing the success of eradication, as has been shown in vitro for cranberry juice ${ }^{12}$. Plants contain multiple organic components including phenols, quinines, terpenoids, flavones and tannins which are known to have bactericidal effects ${ }^{6,13}$. These substances 
are also water soluble and are probably responsible for the killing effect of the plant extracts on H. pylori.

The importance of this study is that it has demonstrated that several plant extracts are effective against $H$. pylori and are obtained simply by boiling parts of the plants.

\section{Acknowledgment}

We are grateful to Mrs. Niluka Velathanthiri and Dr Thanuja Rangani for their assistance in documentation and grant handling and Mr G. Jaykumar and DrThejana for providing samples to isolate Helicobacter pylori strains.

This study was supported by the University GrantUSJP/06/PR/2003.

\section{References}

1. Feldman R.A. (2001). Helicobacter pylori: Molecular and Cellular Biology, (Eds M. Achtman \& S. Suerbaum) pp. 29-51. Horizon Scientific Press, Norfolk, England

2. Mahady G.B., Pendland S.L.,Yun G.S., Lu Z.Z. \& Stoia A. Ginger (2003). (Zingiber officinale Roscoe) and the gingerols growth of Cag A+ strains of Helicobacter pyloriAnticancer Research 23(5A):3699-3702.

3. Takabayashi F., Harada N., Yamada M., Murohisa B. \& Oguni I. (2004). Inhibitory effect of green tea catechins in cc.with sucralfate on Helicobacter pylori infection in Mongolion gerbils. Journal of Gastroenterology 39(1):6163.

4. Canizares P., Gracia I., Gomez L.A., Martain De Argila C., Boixeda D. \& Garcia A. de Rafael L. (2004). Allyl-thiosulfinate bacteriostatic compounds of garlic against Helicobacter pylori. Journal of Biotechnology Progress 20(1):397-401.

5. Tabak M., Armon R., Potasman I. \& Neeman I. (1996). In vitro inhibition of Helicobacter pylori by extracts of thyme. Bacteriology 80(6):667-672.

6. O. Mahony R., Al-Khtheeri Huda, Weerasekara D., Fernando N., Vaira D., Holton J. \& Basset C. (2005). Bactericidal and anti-adhesive properties of culinary and medicinal plants against Helicobacter pylori. World Journal of Gastroenterology 11(47):7499-7507.

7. De Silva M. (1999). Prevalence of H.pylori infection in patients with functional dyspepsia. Ceylon Medical Journal 44(3):118-119.

8. Fernando N., Holton J.,Vaira D., De Silva M. \& Fernando D. (2002). Prevalence of Helicobacter pylori in Sri Lanka as determined by PCR. Journal of Clinical Microbiology 40(7):2675-6 .

9. Jonkers D., van den BroekE., van Dooren I., Thijs C., Dorant E., Hageman G. \& Stobberingh E. (1999). Antibacterial effect of garlic and omeprazole on Helicobacter pylori. Journal of Antimicrobial Chemotherapy 43(6):837-839.

10. Iimuro M., Shibata H., Kawamori T., Matsumoto T., Arakawa T., Sugimura T. \& Wakabayashi K. (2002). Suppressive effect of garlic extract on Helicobacter pylori-induced gastritis in Mongolian gerbils. Cancer Letter 187(1-2): 6 - 68 .

11. Randhir R., Lin Y.T. \& Shetty K. (2004). Phenolics, their antioxidant and antimicrobial activity in dark germinated fenugreek sprouts in response to peptide and phytochemical elicitors. Asia Pacific Journal of Clinical Nutrition 13(3): 295 -307.

12. Shmuely H., Burger O., Neeman I., Yahav J., Samra Z., Niv Y., Sharon N., Weiss E., Athamna A., Tabak M. \& Ofek I. (2004).Susceptibility of Helicobacter pylori isolates to the anti-adhesion activity of a high-molecular -weight constituent of cranberry. Diagnostic Microbiology of Infectious Diseases 50(4):231-235.

13. Cowan M.M. (1999). Plant products as antimicrobial agents. Clinical Microbiology Reviews 12(4):564-582. 